\title{
Dakwah melalui Konseling Islam bagi Masyarakat Desa Simpang Yul
}

\section{Bohhori}

STAIN Syaikh Abdurrahman Siddik Bangka Belitung, Indonesia bohhori89@gmail.com

\begin{abstract}
Simpang Yul merupakan salah satu desa yang berada di Kecamatan Tempilang Kabupaten Bangka Barat, yang masyarakatnya 100\% beragama Islam. Agama Islam yang di anut merupakan agama turunan dari nenek moyang pendahulu di Desa tersebut. Namun, keberagamaan masyarakatnya mengalami berbagai problem baik pada individu atau kelompok pemeluk agama. Ajaran Islam yang disampaikan oleh para da'i dirasa belum bisa menjadi penyelamat serta belum mampu menyelsaikan problematika yang terjadi. Dikarenakan, dakwah yang dilakukan pada masyarakat desa Simpang Yul hanya memfokuskan pada penyampaian materi atau isi pesan-pesan dakwah, tanpa memahami kondisi individu atau kelompok yang akan menerima isi pesan-pesan dakwah dan pola yang digunakan sangat minimalis. Berdasarkan hal itu, konseling Islam dilakukan pada masyarakat sebagai salah satu alternatif dalam berdakwah bagi masyarakatnya. Adapun konseling yang dilakukan dengan cara melakukan identifikasi masalah, untuk mengungkapkan latarbelakang problem yang terjadi kemudian berdasarkan identifikasi masalah menetukan apa masalahnya (diagnosis), dilanjutkan dengan merancang alternatif penyelsaian maslah atas keberagaman bagi inidividu dan kelompok (Prognosis), selanjutnya (Treatmen) melaksanakan pemberian bantuan kepada individu dan kelompok berdasarkan alternatif yang telah dirancang sebelumnya. Dan langkah terahir melakukan evaluasi mengenai proses konseling silam dari tahap identifikasi maslah hingga treatmen dan mengevaluasi hasil yang dicapai dari konseling yang telah dilakukan, sebeagai langkah menentukan apakah masih perlu dilakukan konseling isalam atau tidak.
\end{abstract}

Keywords; Konseling Islam, Dakwah dan Masyarakat Simpang Yul.

Received: 04-10-2017; accepted: 14-11-2017; published: 02-12-2017

Citation: Bohhori, 'Dakwah melalui Konseling Islam bagi Masyarakat Simpang Yul', Mawa'izh, vol. 8, no. 2 (2017), pp. 325-341. 


\section{A. Pendahuluan}

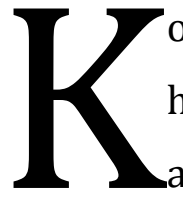

onseling Islam hadir untuk membantu meyelesaikan masalah yang di hadapi oleh Individu atau kelompok sehingga berbahagia di dunia dan akhirat ${ }^{1}$. Sehingga masalah manusia yang bersifat menghambat, merintangi, dan mempersempit dapat diselsesaikan dengan baik dan kemudian memungkinan seseorang untuk berhasil mencapai yang diingginkan. Selain itu, layanan konseling Islam dapat digunakan sebagai salah satu alternatif dalam berdakwah.

Dakwah alternatif ini penting dilakukan mengingat kondisi masyarakat yang beranekaragam. Agar dalam berdakwah dapat mentransformasi, mengimplementasi, dan membahasakan suara Tuhan (kalam Allah) kepada makhluk-Nya, agar dimengerti, difahami, dan dilaksanakan mengenai segala sesuatu yang menyangkut hubungan manusia dengan Tuhannya, manusia dengan sesamanya, dan manusia dengan alam. ${ }^{2}$ Sehingga Intisari suara Tuhan yang merupakan intisari dakwah Islamiyah, berbicara tentang aqidah, ibadah, dan mu'amalah dapat dicapai tujuan dan target dakwah yang diinginkan. ${ }^{3}$ Adapun fokus pemikiran dakwah Islamiyah adalah memberi pengertian kepada umat manusia agar mengamalkan ajaran Allah yang terkandung di dalam Al-Qur'an sebagai jalan hidupnya. Ajaran Allah yang diintisarikan dari Al-Qur'an terdiri dari "aqidah" dan "syari'ah", atau dengan istilah lain "iman" dan "amal shaleh". 4

Dakwah bagi masyarakat yang beranekaragam dengan berbagai problematikanya dalam suatu wilayah harus menyentuh pembinaan dan pembentukan pribadi (takwinu al fardiyah), pembentukan keluarga (takwinu al usroh),dan pembentukan masyarakat Islam (takwinu jama'ati al-Islamiyah) secara keseluruhan. ${ }^{5}$ Namun dalam kegiatan berdakwah juga harus ditunjang dengan kemampuan untuk bisa menunjukkan mereka jalan yang benar baik urusan duniawi

1 Tohari musnawar, Dasar-dasar Konseptual Bimbingan dan Konseling Islam (Yogyakarta: UII Press:, 1992), p. 92.

2 Endang Saifuddin Anshari, Wawasan Islam Pokok-pokok Dasar-dasar Konseptual Bimbingan dan Konseling Islam Pikiran Tentang Islam dan Ummatnya (Jakarta: Raja Grafindo Persada, 1993), p. 19.

3 Said Quthub, Tafsir Fi Dhilalil Qur'an, jilid I (Beirut: Ihyaut Turasil Araby, tth), p. 13.

${ }^{4}$ A. Hasjimi, Dustur Dakwah Menurut Al-Qur'an (Jakarta: Bulan Bintang, 1994), p. 3.

5 Sayid Muhammad Nuh, Dakwah fardiyah: Pendekatan Persoalan dalam Dakwah (Solo: Era Intermedia, 2000), p. 16. 
maupun akhirat, dengan cara merealisasikan ajaran tuhan dalam ucapan dan amalan, menyeru kepada yang ma'ruf dan mencegah dari yang munkar, membimbing mereka pada "shirathu al mustaqim", yang didukung oleh kemampuan dan kesabaran dalam masalah masyarakat Islam (al-mad'u) yang begitu kompleks. ${ }^{6}$

Demikian juga ketika menghadapi salah satu masyarakat dengan berbabagai problematika seperti masyarakat di desa Simpang Yul, dalam berdakwah harus mempunyai alternatif-alternatif berdakwah. Mengingat kompleksnya persoalan yang dihadapi oleh masayarakat di Simpang Yul baik itu problem pada inidividu dan kelompok dalam keberislamannya. Banyak hal yang dihadapi oleh masyarakat mengenai keberislamannya selama ini yang belum dapat diselesaikan, sehingga membutuhkan penyelesaian yang tepat. Berbagai upaya yang dilakukan oleh para da'i dalam berdakwah masih belum bisa menjawab dan menyelsaikan masalah yang dihadapi.

Hal ini tidak terlepas dari peran para da'i yang hanya memfokuskan meyampaikan materi keislaman dengan menggunkan pola yang sama dan strategi yang sama. Seperti bedakwah dengan cara menyampaiakan materi dakwah pada pengajian dan ceramah agama melalui mimbar-mimbar di masjid-masjid, musolla, rumah warga. Sehingga dakwah yang dilakukan tidak menyentuh seluruh lapisan masyarakat dengan berbagai bentuk karakteristiknya serta persoalan yang dihadapinya. Peran para da'i terlihat "sudah cukup" hanya menyampaikan materi dakwah di masjid-masjid, rumah pegajian, rumah warga dan lain sebagainya tanpa mau memahami kondisi sosial dan ekonomi dari individu. Dari hal itu, menimbulkan masih banyaknya individu yang mengikuti pengajian, mau ikut pengajian dan tidak ikut pengajian, buta dan gelisah atas keberislamannya atau dengan kata lain masih belum bisa menciptakan masyarakat yang memahami agama Islam dan keluar dari problem keberagamaan. ${ }^{7}$

Dakwah dilakukan hanya untuk menyampaikan pesan tanpa perduli dengan kondisi individu atau kelompok sebagai mad'unya. Selain itu, Dakwah diakukan tanpa mau mengukur apakah materi yang disampaikan sudah diterima dengan baik

${ }^{6}$ Taufiq Al-Wa'i, An-Nisaaud Daa'yaat (Kuwait: Kementrian Waqaf, 1989), hlm.8.

7 Wawancara dengan Badan perwakilan Desa (BPD) Simpang Yul BapakAsianto pada tanggal 20 November 2017 
atau tidak, apakah semua orang mendapatkan atau tidak. Sehingga dengan Intensitas dakwah yang dilakukan menjadi suatu yang kurang bermakna.

Dari itu, menjadi penting hadirnya konseling Islam bagi masyarakat di desa simpang yul sebagai salah satu alternatif dalam memberikan solusi atas persoalan keberislaman yang dihadapi. Tidak hanya sekedar menyampaikan materi atau pesan-pesan dakwah, akan tetapi juga ikut memikirkan dan membantu menyelesaikan problem yang dihadapi individu dan kelompok, agar mereka dapat memahami ajaran Islam secara baik dari para da'i. Selain itu, dengan kata lain pentingnya kehadiran konseling Islam untuk memaksimalkan kecenderungan manusia yang mempunyai fitrah cenderung berbuat baik, menolong sesama, dan mendatangkan manfaat bagi banyak orang. ${ }^{8}$

\section{B. Pembahasan}

\section{Problematika Masyarakat Pedesaan}

Berdasarkan penelusuran yang dilakukan masyarakat dan pedesaan ialah dua kata yang mempunyai arti yang berbeda. Masyarakat dapat diartikan golongan besar atau kecil yang terdiri dari beberapa manusia dengan atau karena sendirinya bertalian secara golongan dan pengaruh-mempengaruhi satu sama lain ${ }^{9}$. selain itu, Masyarakat dapat juga diartikan sebagai sekumpulan manusia yang saling berinteraksi ${ }^{10}$. Sedangkan pedesaan seorang sosiolog yang berasal dari Amerika, Paul H. Landis mengungkapkan bahwa perdesaan dapat didefinisikan berdasarkan tiga pemilahan pada tujuan analisis. Pertama, Untuk tujuan analisis statistik, desa didefinisikan sebagai suatu lingkungan yang penduduknya kurang dari 2500 orang, Kedua, Untuk tujuan analisa sosial psikologi, desa didefinisikan sebagai suatu lingkungan yang penduduknya memiliki hubungan yang akrab dan serba informal di antara sesama warganya, Ketiga, untuk tujuan analisa ekonomi, desa di definisikan sebagai suatu lingkungan yang penduduknya tergantung kepada $\operatorname{pertanian}^{11}$.

8 Anwar Sutoyo, Bimbimbngan Dan Konseling Islami (Teori Dan Praktik) (Yogyakarta: Pustaka Pelajar, 2013), p. 198.

${ }^{9}$ Hassan Shadily, Sosiologi Untuk Masyarakat Indonesia (Jakarta: Rineka Cipta, 1993), p. 47.

10 Koentjaraningrat, Pengantar Ilmu Antropologi (Jakarta: Rineka Cipta, 2002), p. 144.

11 Rahardjo, Pengantar Sosiologi Pedesaan dan Pertanian (Yogyakarta: Gadjah Mada University Press, 1999), p. 30 
Berdasarkan dua suku kata masyarakat dan desa dapat digabungkan menjadi satu kesatuan masyarakat pedesaan yang diartikan masyarakat yang memiliki hubungan yang lebih mendalam dan erat dan sistem kehidupan umumnya berkelompok dengan dasar kekeluargaan. Dilihat dari mata pencaharian sebagian besar warga masyarakat menggantungkan hidup dari pertanian. Kehidupan masyarakat bersifat homogen dan Keberagamaan masyarakat desa identik dengan keberagamaan turunan dari nenek moyang yang bermula berdiam diri di desa tersebut. Agama yang di anut oleh masyarakatnya tidak lebih dari satu agama.

Masyarakat pedesaan juga dapat dipahami berdasarkan ciri-ciri dari masyarakat pedesaan itu sendiri; pertama, di dalam masyarakat pedesaan di antara warganya mempunyai hubungan yang lebih mendalam dan erat bila dibandingkan dengan masyarakat pedesaan lainnya di luar batas wilayahnya. Kedua, sistem kehidupan umumnya berkelompok dengan dasar kekeluargaan. Ketiga, sebagian besar warga masyarakat pedesaan hidup dari pertanian. Keempat, masyarakat tersebut homogen, deperti dalam hal mata pencaharian, agama, adat istiadat, dan sebagainya ${ }^{12}$. Terlepas dari hal tersebut, adapun beberapa problem yang terjadi dengan masyarakat desa di antaranya:

\section{a. Ekonomi}

Berbicara mengenai sektor ekonomi masyarakat desa maka tidak akan pernah lepas dari sektor pertanian yang merupakan tumpuan perekonomian bagi masyarakat pedesaan. Di mana pertanian menjadi salah satu denyut nadi perekonomian bagi masyarakatnya. Akan tetapi menjadi sesuatau yang dilematis ketika masyarakat petani tidak memiliki lahan garapan. Hal ini diakibatkan oleh penguasa dan para kaum kapitalis ${ }^{13}$ yang mencoba untuk menguasai lahan-lahan yang ada di daerah pedesaan, sehingga masyarakat yang mayoitas petani menjadi tidak mempunyai lahan garapan jikapun ada hanya sedikit. Banyak petani tetapi tidak memiliki lahan kemudian harus menjadi buruh di desanya sendiri, hal ini

12 http://digilib.uinsby.ac.id/155/3/Bab\%202.pdfdiakses pada tanggal 26 November 2017

13 Menurut Karl Marx salah satu sosiolog cum filsuf yang berasal dari Jerman mengatakan bahwan Kaum kapitalis ialah para pemilik modal yang berusaha menguasai sektor-ektor perekonomian dan berusaha menimbun kekayaan, upah kaum buruh tidak pernah dapat naik untuk mencukupi kebutuhan hidupnya, dan dipaksa untuk hidup dalam kemiskinan, sehingga keberadaan mereka akan menjadi 'penduduk surplus relatif. 
menjadi sesuatu yang ironi mengingat masyarakat pedesaan adalah masyarakat mayoritas yang menggantungkan hidup pada sektor pertanian. Dari hal ini tidak jarang menimbulkan konflik pada masyarakat pedesaan. Selain itu, diperparah lagi belum jelasnya hasil panen dari aktivitas-aktivitas disektor pertanian. Sehingga masyarakat pedesaan dengan faktor ekonomi menghambat seluruh lini kehidupan, baik sektor pertumbuhan perekonomian, pendidikan untuk meningkatkan Sumber daya manusia yang berkualitas memiliki pemahan agama yang mempuni.

b. Kebudayaan

Kebudayaan dapat dipahami bahwa merupakan pandangan hidup dari sekelompok orang dalam bentuk perilaku, kepercayaan, nilai, dan simbol-simbol yang mereka terima tanpa sadar yang semuanya diwariskan melalui proses komunikasi dari satu generasi ke generasi berikutnya. ${ }^{14}$ Atau dapat dikatakan bahwa kebudayaan ialah pemikiran cipta dan karya manusia yang berkembang pada masyarakat. ${ }^{15}$ Selain itu, dipahami juga bahwa kebudyaan Pemikiran dan perbuatan yang dilakukan manusia secara terus menerus pada akhirnya menjadi sebuah tradisi sejalan dengan adanya penyebaran agama tradisi yang ada di masyarakat dipengaruhi oleh ajaran agama yang berkembang. ${ }^{16}$

Perlu dipahami juga bahwa problem yang terjadi pada masyarakat pedesaan yakni banyaknya masuk kebudyaan-kebudayaan baru dari luar tanpa adanya filterisasi sehingga menimbulkan terjadinya pergeseran nilai-nilai yang menjadi identitas masyarakat pedesaan. Pergesaran nilai-nilai ini menjadi lebih dilematis dikarenakan nilai-nilai yang masuk menimbulkan lunturnya budaya-budaya solidaritas, soliditas pada masyarakat pedesaan. Dengan kata lain, nilai-nilai yang ada tidak sesuai lagi dengan ciri khas masyarakat pedesaan yang juga jika di lihat dari sisi agama hubungan sesama manusia menjadi kurang intens. Masyarakat disibukkan memikirkan persoalan yang dihadapi.

14 Menurut Liliweri yang diambil dari artikel http://library. binus. Ac .id / eColls LeThesisdoc/Bab2/2013-1-00459-JP\%20Bab2002.pdf hlm 8 . di akses pada tanggal 26 November 2017

15 Selo Sumarjan, dalam Moch. Sodik et al., Islam dan Budaya Lokal (Yogyakarta: Pokja Akademik UIN Sunan Kalijaga, 2005), p. 8.

16 A. Syahri, Implementasi Agama Islam pada Masyarakat Jawa (Jakarta: Depag 1985), p. 12. 
b. Kondisi Sosial

Masalah pada masyarakat pedesaan yakni kurangnya mentalitas masyarakat sepertig kurang peka akan pembangunan daerahnya sendiri. Sehingga, membuat desa yang ditempati kurang begitu berkembang. Selain itu, kurangnya filterisasi kebudayaan kota menimbulkan masyarakat desa yang cenderung konsumtif. ${ }^{17}$

c. Sumber Daya Manusia yang Rendah

Adapun masalah rendahnya kualitas Sumber daya manusia pada masyarakat pedesaan diakibatkan oleh problem pendidikan baik formal amaupun non formal. Misalnya oleh faktor penunjang Sarana dan prasarana pendidikan yang kurang memadai. Dari hal itu, membuat pendidikan tidak berjalan maksimal yang imbasnya adalah pada kualiatas SDMnya.

\section{Fenomena Dakwah pada masyarakat desa Simpang Yul}

Fenoma dakwah yang dilakukan pada masyarakat di Desa Simpang Yul oleh para da'i dilihat tidak memeiliki banyak parian dalam pelaksanaannya. Adapun bentuk kegiatan dakwah yang dilakukan anatara lain:

a. Pengajian

Pengajian ini menjadi salah satu bentuk dakwah yang paling sering dilakukan pada masyarakat di Simpang Yul. Dikarenakan dakwah dengan cara ini dirasa paling mudah dilakukan dan tidak perlu mengeluarkan dana yang banyak. sehingga dapat diikuti oleh seluruh masyarakatnya. Adapun dana yang digunakan untuk membayar di ambil dari dana sosial khusus untuk kegiatan keagamaan. Lebih lanjut para da'i berasal dari simpang yul tidak satupun yang di bayar, mereka berdakwah demi menyampaikan isi pesan-pesan ajaran Islam bagi masyarakat. Sedangkan para da'i yang berasal dari luar bayarannyapun tidak terlalu tinggi jika dibandingkan dengan para da'i di kota, mereka dibayar hanya untuk mengganti ongkos transportasi perjalanan ke Simpang Yul.

Pengajian di Desa Simpang Yul sudah sejak lama adanya dan hingga saat in terus dikembangkan. Pelaksaan pengajian dilakuakan disesuaikan dengan jadwal yang telah ditentukan oleh setiap pengurus atau pengelola pengajian. Adapun

17 Lihat artikel http://file.upi.edu/Direktori/fpips/jur._pend._geografi/197210242001121bagja_waluya/geografi_desakota/Rural_Comunity.pdf. hlm 4. di akses pada tanggal 26 November 2017 
tempat yang digunakan untuk melaksanakan pengajian diantaranya: Di TPA, Masjid dan Rumah warga. Kegiatan pengajian di Desa Simpang Yul sebanyak 28 tempat yang tersebar di beberapa Dusun di anataranya:, ada 8 pengajian di Dusun Dinai Penegak, ada 11 di dusun Petaling Jaya dan 9 di Dusun Simpang Yul. Adapun yang mengisi pengajian yakni orang asli kelahiran Simpang Yul yang bermukim di Simpang Yul, yang lahir di luar Simpang Yul berdomisili di Simpang Yul dan para da'i dari laur. Latarbelakang pendidikan ilmu agamanya terdiri dari 1 ustadz asal Simpang Yul menamatkan sekolah non formal di pondok pesantren, 7 orang dari guru yang berlatar belakang hanya belajar ilmu agama dari guru keguru atau dari ustadz ke ustadz pada pengjian, 5 orang ustadz kelahiran luar Simpang yul yang berdomisili di simpang yul lulusan Pondok Pesantren, dan 4 orang Ustadz dari Luar Simpang Yul yang tidak berdomisili di Simpang Yul. Sedangkan materi dakwah yang di ajarkan pada masyarakat yakni yang berkaitan dengan akidah, Syari'ah dan tasawuf.

Dari pemaparan di atas, ternyata masih ditemukan masyarakat tidak mengikuti pengajian dengan berbagai problem yang dihadapi, di antaranya:

1) Malu ikut karena tempatnya di masjid dan TPA tempat umum

2) Malu ikut karena pengajian sudah lama berjalan, kalaupun ikut banyak materi yang terttinggal.

3) Yang hadir kebanyakan adalah orang-orang yang sudah lebih paham agama ketimbang masyarakat yang tidak ikut.

4) Pengkajian materinya hanya berkaitan dengan ilmu fiqh, tauhid dan tasauf. tidak ada pembelajaran untuk membaca al-qur'an bagi pemula dan tat cara solat dan lain sebagainya yang berkaitan ilmu praktis sehingga dirasa pengajain kurang cocok.

5) Pengajian di Masjid dan TPA waktunya siang hari, sedangkan waktu siang hari digunakan untuk waktu kerja, sedangkan yang ikut pengajian tersebut ialah mereka-mereka yang mempunyai ekonomi di atas masyarakat yang tidak ikut pengajian.

6) Pengajian sebagian dilakukan adanya pembauran antara anak-anak dan orang dewasa sehingga menimbulkan kegaduhan dan kurang kondusif. 
7) Malu ikut Pengajian di rumah-rumah warga karena baru belajar membaca alur'an baru dari iqro' I dan belajar gerakan solat bagi masyarakat yang sudah dewasa. ${ }^{18}$

Masih menurut beberapa warga yang diwawancara mengatakan bahwa sebenarnya mau belajar tentang ilmu agama Islam. Apalagi beragama Islam tapi belum bisa membaca al-qur'an dan tidak tau cara solat itu malu rasanya. Oleh sebab itu, problematika tersebut perlu sosok yang dapat memahami dan perduli untuk membantu persoalan yang terjadi sesuai dengan keingginan masyarakat tersebut.

b. Ceramah atau tabligh akbar

Kegiatan dakwah dengan tabligh akbar dilakukan hanya pada momenmemoen tertentu saja seperti hari besar Islam seperti maulid nabi, Isra' mi'raj, Nuzulul Qur'an dan hari-hari tertentu lainnya dengan mengundang para da'i dari dalam daerahmaupun luar daerah. Materi yang di sampaikan hanya berkaitan dengan momen-momen tersebut. Kelemahan dari tabligh akbar ini sebagian masyarakat enggan untuk datang karena isi dakwah yang di sampaikan sifatnya hanya pengayaan, materinya hanya sepotong-sepotong tidak mempelajari ajaran Islam yang runtut dan komprehensif. Dan juga jangankan materi pengayaan materi dasar saja tidak paham.

\section{Implementasi Dakwah melalui Konseling Islam}

Dalam perspektif bahasa, konseling berasal dari bahasa Inggris yaitu counseling. Sedangkan kata counseling dari kata to counsel yang artinya memberikan nasehat atau memberi anjuran kepada orang lain secara face to face (berhadapan muka satu sama lain) dan juga bisa diartikan advice, yang artinya nasehat atau petuah $^{19}$. Menurut al-Mawrid ${ }^{20}$ kata "councel" bahasa arabnya adalah نصيحة , yang berarti nasehat yang baik.

Sebelum menjelaskan maksud konseling Islam penulis memamparkan bahwa dalam konseling terdapat dua pemahaman yakni konseling umum dan islam.

18 Wawancara dengan Rudi, Jahok, dan Siman pada tangggal 27 November 2017

19 Jhon M. Echols \& Hassan Shadily, Kamus Inggris Indonesia (Jakarta: PT. Gramedia 1992), p. 150.

20 Munir Baalbaki Al Mawrid, Kamus Inggris-Arab (Beirut: Dar El- Ilm-lil-Malayen, 1996), p. 222. 
Namun, dari kedua hal tersebut tidak ada perbedaan yang signifikan, adapun Menurut Shretzer \& Stone ${ }^{21}$ konseling adalah suatu proses interaksi yang memudahkan pengertian diri dan lingkungan serta hasil-hasil pembentukan dan atau klarifikasi tujuan-tujuan dan nilai-nilai yang berguna bagi tingkah laku yang akan datang. Dari beberapa pendapat tersebut dapat dipahami bahwa konseling adalah suatu proses pemberian bantuan yang dilakukan oleh seorang ahli kepada individu yang sedang mengalami masalah, agar individu dapat mengatasi permasalahan yang dihadapinya. Selain itu, Menurut Langgulung ${ }^{22}$ konseling adalah proses yang bertujuan menolong seseorang yang mengidap kegoncangan emosi sosial yang belum sampai pada tingkat kegoncangan psikologis atau kegoncangan akal, agar ia dapat menghindari diri dari padanya. Sejalan dengan pendapat tersebut, Priyatno \& Anti ${ }^{23}$ menyatakan bahwa konseling adalah proses pemberian bantuan yang dilakukan melalui wawancara konseling oleh seorang ahli (disebut konselor) kepada individu yang sedang mengalami suatu masalah (disebut klien), yang bermuara pada teratasinya masalah yang dihadapi oleh klien.

Menurut Adz-Dzaky konseling islami ialah suatu aktivitas memberikan bimbingan, pelajaran dan pedoman kepada individu yang meminta bimbingan (konseli) dalam hal bagaimana seharusnya seorang konseli dapat mengembangkan potensi akal fikirannya, kejiwaannya, keimanan, dan keyakinan serta dapat menanggulangi problematika hidup dan kehidupannya dengan baik dan benar secara mandiri yang berparadigma kepada Al-Qur'an dan As-Sunnah Rasulullah ${ }^{24}$.

Sedangkan Menurut Komarudin, konseling Islam adalah proses pemberian bantuan kepada seorang individu atau kelompok yang tidak lepas dari nilai-nilai keislaman berdasarkan Qur'an dan hadits, untuk menjadi penerang bagi seluruh

${ }^{21}$ Bruce Shretzer and, Shelly C Stone, Fundamental of Guidance (Indiana: Purdue University, 1968), p. 26. 452.

${ }^{22}$ Langgulung, Hasan, Teori-Teori Kesehatan Mental (Jakarta: Pustaka Al-Husna, 1986), p. p. 105.

${ }^{23}$ Priyatno \& Anti, Dasar-Dasar Bimbingan dan Konseling (Jakarta: PT. Bineka Cipta, 1999),

24 M. Hamdani Bakran Adz-Dzaky, Psikoterapi dan Konseling Islam (Yogyakarta: Fajar Pustaka Baru, 2001), p. 137. 
umat manusia. Guna mengantarkan manusia kepada kebahagiaan lahir batin di dunia dan akhirat 25 .

Berdasarkan pemaparan tersebut di atas, dapat dipahami bahwa tidak ada perbedaan pendapat mengenai konsep konseling umum dan islami dalam proses pemberian bantuan terhadap individu, namun dalam konseling Islam konsepnya bersumber pada Al-Qur'an dan Hadist.

Hakekat bimbingan dan konseling Islami adalah upaya membantu individu belajar mengembangkan fitrah dan atau kembali kepada fitrah-iman dan atau kembali kepada fitrah-iman, dengan cara memperdayakan (empowering) fitrahfitrah (jasmani, rohani, nafs, dan iman) mempelajari dan melaksanakan tuntutan Allah dan rasul-Nya, agar fitrah yang ada pada individu berkembang dan berfungsi dengan baik dan benar. Pada akhirnya diharapkan agar individu selamat dan memperoleh kebahagiaan yang sejati di dunia dan akhirat ${ }^{26}$. Dari rumusan di atas tampak, bahwa konseling Islam adalah aktifitas yang bersifat "membantu", dikatakan membantu karena pada hakekatnya individu sendirilah yang perlu hidup sesuai tuntutan Allah (jalan yang lurus) agar mereka selamat. Karena posisi konselor bersifat membantu, maka konsekuensinya individu sendiri yang harus aktif belajar memahami dan sekaligus melaksanakan tuntutan Islam (alQur"an dan sunah rasul-Nya). Pada akhirnya diharapkan agar individu selamat dan memperoleh kebahagiaan yang sejati di dunia dan akhirat, bukan sebaliknya kesengsaraan dan kemelaratan di dunia dan akhirat ${ }^{27}$.

Implementasi menurut Kamus Besar Bahasa Indonesia adalah pelaksanaan, penerapan ${ }^{28}$. Implementasi merupakan suatu proses penerapan ide, konsep, kebijakan atau inovasi dalam suatu tindakan praktis sehingga memberikan dampak, baik berupa pengetahuan, ketrampilan, maupun nilai dan sikap ${ }^{29}$. pp. 54-5.

${ }^{25}$ Komaruddin, dkk, Dakwah dan Konseling Islam (Semarang: PT Pustaka Rizki Putra, 2008),

${ }^{26}$ Anwar Sutoyo, Bimbingan \& Konseling Islami (Teori dan Praktik), (Yogyakarta: Pustaka Pelajar, 2003), p. 207. 10.

27 Anwar Sutoyo, Bimbingan \& Konseling Islami, p. 22

28 Tim Penyusun Kamus Besar Pusat Pembinaan dan Pengembangan Bahasa, Kamus Besar Bahasa Indonesia (Jakarta: Balai Pustaka, 1988), p. 327.

29 E. Mulyasa, Kurikulum Berbasis Kompetensi (Konsep, Karakteristik, Implementasi, dan Inovasi) (Bandung: PT. Remaja Rosdakarya, 2003), p. 93. 
Adapun maksud dari implementasi dakwah melalui konseling Islam ini melakukan proses penyampaian isi pesan-pesan atau materi dakwah melalui konseling Islam sesuai dengan tahapan-tahapan sebagaimana yang dijelaskan pada pelaksanaan pada poin 5 tahapan konseling Islam.

Dalam implementasi dakwah melalui konseling Islam beberapa tahapan yang harus dilalui 30 diantaranya:

1. Identifikasi masalah

Proses ini adalah untuk mengenal gejala-gejala dari suatau masalah yang sedang di hadapi. Gejala yang berkaitan dengan mengapa individu tidak dapat menerima ajaran Islam, tidak mau belajar tentang ajaran islam, tidak mengamalkan nilai-nilai ajaran Islam dan lain sebagainya. Gejala yang tampak ini menjadi sesuatu yang penting untuk diamati agar proses selanjutnya lebih mudah untuk bisa melakukan pemberian bantuan atas dasar mengetaui bahwa seseorang individu mempeunyai masalah dengan dirinya atau kelompok mempunyai problem yang tidak jauh berbeda dengan kelompoknya. Tingkah laku yang tampak yang diketahui memudahkan untuk bisa menguarai dan melakukan penetapan kesimpulan yang melatar belakangi maslah yang terjadi.

2. Melakukan diagnosis

Setelah masalah dapat diidentifikasi, pada langkah diagnosis ini adalah menetapkan masalah tersebut berdasarkan anlisis latar belakang yang menjadi penyebab timbulnya masalah pada individu atau kelompok masyarakat. Pada tahapan diagnosis ini mengumpulkan data mengenai berbagai hal yang melatar belakangi atau menyebabkannya gejala yang terjadi. Sehingga ditemukan sesuatu yang menjadi pokok latar belakang terjadinya dan menemukan masalah. Hal ini dilakukan sebagai upaya lanjutan dari identifikasi masalah dan dilanjutkan untuk bisa merancang cara penyelesaian masalah yangs edang dihadapi oleh individu.

3. Menetapkan Pragnosis

Penetapan prognosis upaya melanjutkan kegiatan diagnosis atas masalah yang sedang dihadapi. Prognosis ini adalah merancang alternatif cara melaksanakan

30 Akhmad Muhaimin Azzet. Bimbingan dan Konseling di Sekolah (Jakarta: AR-RUZZ Media, 2012), pp. 65-71 
atau metode-metode yang digunakan dalam memberikan bantuan serta menetapkan materi yang perlu disampaikan yang berkaitan dengan kondisi individu yang bermasalah atau untuk proses pencegahan akan terjadinya masalah.

\section{Treatmen}

Setelah menetapkan pragnosis selanjutnya merealisasikan langkah-langkah alternatif yakni memberikan bantuan berdasarkan masalah dan latar belakang yang menjadi penyebabnya. Pemberian bantuan ini secara continue untuk mencapai keberhasilan menyelsaikan persoalan yang ada. Treatmen ini langkah memberikan bantuan sesuai dengan yang telah ditentukan sebelumya baik itu materi, metode, media atau hal-hal lain yang telah ditetapkan. Materi yang diberikan baik berupa Nasehat, Motivasi, Nilai-nilai Ajaran Islam dan lain sebagainya.

5. Evaluasi dan Tindak Lanjut

Langkah selanjutnya adalah evaluasi dari pertemuan atau proses pada waktu bimbingan dan konseling untuk mengetahui perubahan yang terjadi.

Dari uraian mengenai langkah-langkah implementasi dakwah melalui layanan konseling menjadi pokok masalah ialah seorang da'i mengetahui kondisi mad'unya, mengetaui latar belakang msalahnya, tau dengan masalahnya, bisa merancang kegiatan untuk tahapan penyelsaian masalah, melaksanakan langkahlangkah baik pencegahan atau terapi. Pada tahap ahir yakni melakukan evalasi baik itu proses yang telah dilalui ataupun hasil yang di dapat dari implementasi dakwah melalui konseling Islam.

\section{Aspek-Aspek Bimbingan dan Konseling Islam}

Dalam konseling Islam memiliki tiga aspek ${ }^{31}$ yakni Preventif, perkembangan dan Terapi yang menjadi pokok pembahasan. Adapun 3 aspek yang dimaksud:

a. Aspek Preventif

Aspek preventif orientasinya dalam pelaksanaan konseling Islam yang dilakukan oleh da'i atau konselor berupaya untuk mengarah kepada pengembangan strategi-strategi dan program-program yang dapat digunakan untuk mencoba mengantisipasi dan megelakan resiko-resiko hidup yang tidak perlu terjadi bagi

${ }^{31}$ Musfir, Konseling Terapi (Jakarta: Gema Insani, 2005), p. 24. 
masyarakat pedesaan ${ }^{32}$. Selain itu, dengan kata lain aspek preventif dilakukan oleh Da'i atau konselor sebagai upaya untuk penjagaan individu dari semua guncangan jiwa dan membentengi mereka dari segala penyimpangan sehingga masalahmasalah yang terjadi dengan kejiwaan yang dilatar belakangi oleh kondisi-kondisi internal dari dalam diri dan dari luar.

Diberikan penjagaan agar individu atau kelompok terhindar dari masalahmasalah sosial dalam proses keberagamaan seorang individu. Penjagaan dari masalah untuk mengantisipasi kemungkinan-kemungkinan tekanan yang dapat mengganggu pikiran dan emosi-emosi dari individu untuk mengambil keputusan yang sesuai dengan tuntunan nilai-nilai ajaran islam. Dan juga untuk menghindarkan individu agar selalu semangat untuk belajar tentang agama, mengikuti dan mengamalkan nilai-nilai ajaran islam. Serta memahami konsep ketauhidan yang di amalkan ketika hidup dalam suatu masyarakat.

Kegiatan konseling Islam yang dilakukan untuk bisa mencapai tujuan yakni melakukan kegitan yang secara garis besar meliputi:

- Membantu individu mengetahui, mengenal dan memahami keadaan dirinya sesuai dengan hakikatnya, atau memahami kembali dirinya. Untuk apa hidup di dunia dan apa yang perlu dipersiapkan untuk bisa mencapai kebahagiaan di akhirat nanti.

- Membantu individu menerima keadaan dirinya sebagaiman adanya, sehingga tidak banyak bergantung kepada orang lain dan optimis selalu berikhtiar untuk mencapai kebahagiaan di dunia dan juga akirat.

- Membantu inidvidu memahami keadaan situasi dan kondiis yang terjadi dan dihadapi saat ini. Sehingga dapat mengambil keputusan yang tepat dapat lepas dari jeratan masalah yang mengganggu keberagamaan dari individu ${ }^{33}$.

b. Aspek Perkembangan

Aspek perkembangan orientasinya mengarah kepada pembentukan keperibadian muslim agar mampu menjadi individu yang optimis, penuh dengan

${ }^{32}$ Abdul Cholid Dahlan, Bimbingan dan Konseling Islami: Sejarah, Konsep, dan Pendekatannya (Yogyakarta: Pura Pustaka, 2009), pp. 51-2.

33 Ibid, 
produktivitas serta mampu mengoptimalkan segala potensi dan kemampunnya sehingg tidak terjadi persoalan terhadap individu atau kelompok.

c. Aspek Terapi

Aspek terapi orientasiya mengarah kepada pembebasan dan pelepasan individu dari segala kekhawatiran dan kegelisahannya serta membantu dalam memcahkan masalah yang dihadapinya. Baik itu berupa memberikan motivasi, advokasi, atau memberikan alternatif penyelsaian masalah dengan cara menyampaikan nasehat dengan materi yang bernilai ajaran-ajaran pokok islam.

Penggamabaran Islam akan konseling islami dapat menunjukan pandangan Islam akan tabiat manusia mengenai pandangan bahwa:

- Pada dasarnya, semua manusia itu baik, namun ia punmampu memilih untuk berbuat hal yang buruk dan inilah titik kelemahan manusia.

- Pangkal dasar kegelisahan yakni pada ketiadaan dan juga jauhnya seseorang dari Akidah Islam.

- Perilaku bisa diubah.

- Pemberian konseling sesuai dengan keadaan yang ada.

- Menerapkan konseling yang saling melengkapi dan menimbulkan sikap optimisme dalam aspek kesehatan, diri dan juga masyarakat.

- Menerapkan konseling yang berkesinambungan di semua fase perkembangan.

- Menerapkan konseling yang memberikan kemudahan di semua aspek keperibadian individu. ${ }^{34}$

\section{Tahapan Konseling Islam bagi masyarakat di Simpang Yul}

Dakwah yang dilakukan di Simpang yul dengan pengajian dan tablig akbar, hanya mementingkan aspek menyampaikan isi pesan-pesan dakwah atau hanya memfokuskan pada penyampaian materi tanpa mau perduli dengan kondisi pribadi dari individu karena masalah kejiwaan inidvidu bagi masyarakat simpang yul bukan persoalan dakwah. sehingga konseling Islam di anggap menjadi salah satu alternatif yang tepat dalam berdakwah pada masyarakat simpang yul dengan tahapan:

Melakukan identifikasi masalah dengan mengmpulkan data untuk mengetahi masalah yang dihadapi oleh masyarakat Simpang Yul dengan cara wawancara

${ }^{34}$ Musfir, Konseling Terapi, p.p 25-6. 
kepada individu-inidividu dan kelompok yang tidak ikut pengajian atau jarang beribadah dan melakukan observasi di seputaran wilayah simpang Yul sehingga diketahui masalah yang dihadapi masyarakat. Kemudian berdasarkan identifikasi masalah dapat ditentukan masalah (Diagnosis) yang sedang dihadapi oleh masyarakat seperti kurang percaya diri, kekeliruan konsep berpikir mengenai pengajian dan tabligh akbar, kurangnya keingginan untuk belajar agama, merasa benci dengan yang belajar agama, merasa tidak pantas lagi belajar agama, dan merasa enggan untuk belajar agama karena gama tidak memberikan solusi atas masalah yang sedang dihadapi (merasa benci dengan realitas keberagamaan dikalangan para Abid atau ahli ibadah. Kemudian menetukan alternatif langkahlangkah penyelsaian masalah (Prognosis) dengan beberapa alternatif yakni: menyampaikan masalah-masalah yang dihadapi oleh masyarakat simpang yul kepada para da'i dan meminta kepada para da'ia agar berdakwah di mulai dari yang tidak dipahami dan menyampaiakn materi yang inggin diketahui oleh masyarakat misalnya tentang tata acara solat, membaca al-qur'an dan lain sebagainya. Selain itu, mengisi pengajian waktu dan tempatnya disesuaikan dengan keingginan dari masyarakat, tempatnya bisa di rumah warga yang jauh dari keramaian atau di gang atapun dipondok kebun. Selain itu, konselor atau pembimbing akan memberikan materi-materi motivasi yang berkaitan fadilah ibadah, pentingnya beribadah, belajar agama (menuntut Ilmu), serta pentingnya membangun rasa percaya diri. Di tambah dengan menyampaikan materi yang berkaitan dengan kebutuhan yang diras diperlukan mendesak oleh masyarakat seperti tat cara solat, bersuci dan lain sebagainya. Selanjutnya melaksanakan cara yang perlu ditempuh yag sudah ditetapkan sebelumnya (treatment) melakukan obrolan Diskusi, menyampaikan informasi atasa masalah yang dihadapi dan memberikan masukan yang perlu dilakukan oleh para da'i serta menyampaikan materi yang sudah ditetapkan di atas. Yang terahir konselor atau pembimbing melakukan evaluasi atas apa yang telah dilakukan. 


\section{DAFTAR PUSTAKA}

Adz-Dzaky, M. Hamdani Bakran, Psikoterapi dan Konseling Islam, Yogyakarta: Fajar Pustaka Baru, 2001.

Al Mawrid, Munir Baalbaki, Kamus Inggris - Arab, Beirut: Dar El- Ilm- lilMalayen, 1996

Al-Wa'i, Staufiq, An-Nisaaud Daa'yaat, Kuwait: Kementrian Waqaf, 1989

Anshari, Endang Saifuddin, Wawasan Islam Pokok-pokok Pikiran Tentang Islam dan Ummatnya, Jakarta: Raja Grafindo Persada, 1993.

Azzet, Akhmad Muhaimin, Bimbingan dan konseling di sekolah, Jakarta: ARRUZZ Media, 2012.

Dahlan, Abdul Cholid, Bimbingan dan Konseling Islami: Sejarah, Konsep, dan Pendekatannya, Yogyakarta: Pura Pustaka, 2009.

Echols, Jhon M. \& Shadily, Hassan, Kamus Inggris Indonesia, Jakarta: PT. Gramedia, 1992.

Hasjimi, A, Dustur Dakwah Menurut Al-Qur'an, Jakarta: Bulan Bintang, 1994. Koentjaraningrat, Pengantar Ilmu Antropologi, Jakarta: Rineka Cipta, 2002.

Komaruddin, dkk, Dakwah dan Konseling Islam, Semarang: PT Pustaka Rizki Putra, 2008.

Langgulung, Hasan, Teori-Teori Kesehatan Mental, Jakarta: Pustaka AlHusna, 1986.

Mulyasa, E, Kurikulum Berbasis Kompetensi (Konsep, Karakteristik, Implementasi, dan Inovasi), Bandung: PT. Remaja Rosdakarya, 2003.

Musfir, Konseling Terapi, Jakarta: Gema Insani, 2005.

Musnawar, Tohari, Dasar-dasar Konseptual Bimbingan dan Konseling Islam Yogyakarta: UII Press, 1992.

Nuh, Sayid Muhammad, Dakwah fardiyah: Pendekatan Persoalan dalam Dakwah, Solo: Era Intermedia, 2000

Priyatno \& Anti, Dasar-Dasar Bimbingan dan Konseling, Jakarta: PT. Bineka Cipta, 1999.

Quthub, Said, Tafsir Fi Dhilalil Qur'an, jilid I, Beirut: Ihyaut Turasil Araby, Tth.

Rahardjo, Pengantar Sosiologi Pedesaan dan Pertanian, Yogyakarta: Gadjah Mada University Press, 1999.

Sutoyo, Anwar, Bimbingan dan Konseling Islami (Teori dan Praktik), Yogyakarta: Pustaka Pelajar, 2013.

Shadily, Hassan, Sosiologi untuk Masyarakat Indonesia, Jakarta: Rineka Cipta, 1993.

Sodik, Moch. et al, Islam dan Budaya Lokal, Yogyakarta: Okja Akademik UIN Sunan Kalijaga, 2005.

Syahri, A, Implementasi Agama Islam pada Masyarakat Jawa, Jakarta: Depag 1985.

Shretzer, Bruce and Stone, Shelly C, Fundamental of Guidance, Indiana: Purdue University, 1968.

Sutoyo, Anwar, Bimbingan \& Konseling Islami (Teori dan Praktik), Yogyakarta: Pustaka Pelajar, 2003.

Tim Penyusun Kamus Besar Pusat Pembinaan dan Pengembangan Bahasa, Kamus Besar Bahasa Indonesia, Jakarta: Balai Pustaka, 1988. 